\title{
The EU's Failure to Support Member States in their Implementation of the WHO Recommendations: How to Ignore the Elephant in the Room?
}

\author{
Oliver BARTLETT* and Amandine GARDE**
}

\section{INTRODUCTION}

WHO Recommendation 8 urges Member States to regulate the cross-border marketing of unhealthy food. This concern has become even more pressing than it was in 2010 in light of the advance of digital marketing and other forms of marketing, ${ }^{1}$ which are inherently cross-border and therefore more difficult to regulate at national level by States individually. However, cross-border marketing regulation will only be useful to Member States if it is sufficiently robust; if not, the risk is that it may hinder rather than support their efforts at national level.

The EU provides a unique case study in light of the nature of the EU legal order and the powers it has been granted by Member States to "adopt the measures for the approximation of the provisions laid down by law, regulation or administrative action in Member States which have as their object the establishment and functioning of the internal market". 2 The adoption of common rules on the marketing of tobacco products demonstrates how far the tobacco control policies of Member States can be supported by the adoption of EU harmonising rules. Not only does the Tobacco Advertising Directive prohibits all cross-border advertising and sponsorship of tobacco products, ${ }^{3}$ but the Tobacco Products Directive ${ }^{4}$ also regulates the marketing of electronic cigarettes and imposes restrictions on the use of tobacco packets as advertising tools. The constitutional legitimacy of both directives has been upheld by the Court of Justice of the European Union (CJEU), ${ }^{5}$ confirming that the EU has both the constitutional power and mandate to

\footnotetext{
* University of Liverpool, ojb@liverpool.ac.uk.

** University of Liverpool, agarde@liverpool.ac.uk.

1 According to the Marketing Budgets Report 2016, the trend towards increased use of digital marketing strategies continues: in $201672 \%$ of companies surveyed increased their digital marketing budget. See P Pinto, "The Rise of Digital Marketing" (22 September 2016, beeseensolutions.com). On the problems associated with the digital marketing of unhealthy food to children, see Tackling food marketing to children in a digital word: trans-disciplinary perspectives (Copenhagen, WHO Regional Office for Europe, 2016).

2 Art. 114(1) TFEU.

Directive 2003/33, OJ L 152, 20.6.2003, pp. 16-19.

Directive 2014/40, OJ L 127, 29.4.2014, pp. 1-38.

Case 380/03 Germany v Parliament and Council [2006] ECLI:EU:C:2006:772; Case C-547/14 Philip Morris Brands [2016] ECLI:EU:C:2016:325.
} 
adopt EU-wide standards on the marketing of tobacco products, so long as these standards are connected in some genuine way to removing barriers to the functioning of the internal market.

Regrettably, however, the cross-border regulation of unhealthy food marketing paints a strikingly different picture. It is true that the EU and its Member States are not bound by the WHO Recommendations as they are by the WHO Framework Convention on Tobacco Control. Nevertheless, the EU is under an obligation to ensure a high level of public health protection in the development and implementation of all its policies, including its internal market policy, ${ }^{6}$ and its action should be guided by its overarching objective of promoting the well-being of its people. The EU has extensive powers to regulate the marketing of unhealthy food to children, and the evidence associating unhealthy food marketing with childhood obesity calls for a robust response at both national and EU levels. ${ }^{7}$

This contribution argues that the EU has failed to adopt evidence-based policies intended to restrict the impact of unhealthy food marketing on children's health. The key provision of relevance to this debate - Article 9(2) of the Audio Visual Media Services (AVMS) Directive ${ }^{8}-$ merely calls on for the adoption of industry codes of conduct intended to limit audiovisual commercial communications for unhealthy food in children's programmes. As we will discuss in section II below, the gaps between the WHO Recommendations and this provision are significant, and hope is fading that the EU is going to revise the AVMS Directive in a way that will offer more protection to children from the harmful impact of unhealthy food marketing. This situation is all the more difficult to grasp in light, firstly, of the research that the EU has commissioned and that supports further restrictions, and secondly, of the concerted effort that the public health community has made to ensure that the question of the impact of unhealthy food marketing on children was brought to the fore in the public debate and that the limits of the existing regulatory framework would be clearly exposed.

In the complete absence of political will to adopt a robust EU-wide policy response, the question arises how Member States can implement the WHO Recommendations at national level. It is a basic principle of EU internal market law that, in the absence of harmonised rules, Member States retain their freedom to regulate the marketing of goods, services and brands on their territories, on the condition that they comply with the general free movement Treaty provisions, not least Article 34 TFEU on the free movement of goods and Article 56 TFEU on the free movement of services. The third section of this contribution focuses on the case law of the CJEU, with a particular regard for the limits it has placed on the freedom of Member States to regulate marketing practices to ensure a high level of public health. It will show that Member States do retain

\footnotetext{
6 Art. 168(1) TFEU, Art. 114(3) TFEU, Art. 9 TFEU and Art. 35 of the EU Charter on Fundamental Rights.

7 A Alemanno and A Garde, "The Emergence of an EU Lifestyle Policy: The Case of Alcohol, Tobacco and Unhealthy Diets" (2013) 50(6) Common Market Law Review 1745; F Geber, "Between a rock and a hard place: the controversial case of legislative harmonization and national lifestyle policies" and A Garde and M Friant-Perrot, "The regulation of marketing practices for tobacco, alcoholic beverages and foods high in fat, sugar and salt - a highly fragmented landscape", both in A Alemanno and A Garde (eds), Regulating Lifestyle Risks: The EU, Alcohol, Tobacco and Unhealthy Diets (Cambridge University Press, 2015); O Bartlett, "The EU's Competence Gap in Public Health and Non-Communicable Disease Policy” (2016) 5(1) Cambridge Journal of International and Comparative Law 50.

8 Directive 2010/13, OJ L 95, 15.4.2010, pp. 1-24.
} 
a wide margin of discretion to protect the health of their citizens, particularly the most vulnerable, but that they bear the onus of demonstrating how the measures they adopt are proportionate to the objectives that they have identified, in this case to protect children from the harmful impact that unhealthy food marketing has on their health.

\section{RESTRICTING THE CROSS-BORDER MARKETING OF UNHEALTHY FOOD AT EU LEVEL}

After briefly presenting Article 9(2) of the AVMS Directive as the key provision relating to the regulation of food marketing to children (1), this section focuses on the unfolding revision process of the AVMS Directive, attempting to draw some key themes and tentative conclusions (2).

\section{Directive 2010/13 on Audiovisual Media Services and its failure to contribute to an effective implementation of the WHO Recommendations}

This section does not propose to rehearse in detail the legislative history of Directive 2010/13. This has been done elsewhere. ${ }^{9}$ Suffice it to say, for our purposes, that Article 9(2) was inserted in 2007 as part of the EU's obesity prevention strategy, thus recognising that food marketing contributes to the obesogenic environment responsible for growing childhood overweight and obesity rates. ${ }^{10}$ Since then, Member States have adopted the EU Action Plan on Childhood Obesity 2014-2020 which further acknowledges that unhealthy food marketing is part of the problem of childhood obesity and must be addressed. ${ }^{11}$ However, the EU's response to unhealthy food marketing to date has largely been ineffective.

The main provision of EU law purporting to address the exposure of children to unhealthy food marketing is Article 9(2) of the AVMS Directive, which provides:

Member States and the Commission shall encourage media service providers to develop codes of conduct regarding inappropriate audiovisual commercial communications, accompanying or included in children's programmes, of foods and beverages containing nutrients and substances with a nutritional or physiological effect, in particular those such as fat, trans-fatty acids, salt/sodium and sugars, excessive intakes of which in the overall diet are not recommended.

Not only does this provision rely on the ineffective mechanism of self-regulation, as discussed more fully in the previous contribution to this Special Issue, but it also contains gaping holes that allow even more freedom to industry operators to define the scope of their codes of conduct narrowly, leaving a broad range of programmes, media and marketing techniques outside the purview of the EU. This should not be read as suggesting that the EU should regulate all forms of unhealthy food marketing; this would infringe the principle of conferred powers, as the EU painfully realised when the CJEU

\footnotetext{
9 See in particular A Garde, EU Law and Obesity Prevention (Alphen Aan de Rijn, Kluwer Law International, 2010) ch 5; and O Bartlett and A Garde, "Time to seize the (red) bull by the horns: the EU's failure to protect children from alcohol and unhealthy food marketing” (2013) 38(4) European Law Review 498.

10 White Paper on A Strategy for Europe on Nutrition, Overweight and Obesity related health issues, COM(2007) 279 final.

11 EU Action Plan on Childhood Obesity 2014-2020, available at ec.europa.eu/health//sites/health/files/nutrition physical_activity/docs/childhoodobesity_actionplan_2014_2020_en.pdf (last accessed 24 May 2017).
} 
annulled the First Tobacco Advertising Directive in 2000. ${ }^{12}$ Rather, we are suggesting that the EU reflect on how it should regulate cross-border marketing for unhealthy food.

Article 9(2) and the AVMS Directive more generally fall short of implementing the WHO Recommendations in several respects, insofar as their scope is limited and cannot promote the comprehensive approach that Recommendations 2 and 3 call for. Firstly, by only referring to "audiovisual commercial communications accompanying or included in children's programmes", this provision is unlikely to significantly reduce (if at all) the overall exposure of children to unhealthy food marketing. As the UK case study below clearly shows, most of the television that children watch is outside children's programmes; rather, they view programmes intended for mixed audiences. The fact that the proportion of children does not exceed $35 \%$ of the total audience, as per the EU Pledge, does not mean that many children in absolute numbers are not members of the audience. The research that the EU commissioned on the exposure of children to alcohol marketing strongly supports this assessment, in that it has shown that for children aged 4-14 the part of the day with the highest average hourly viewing rates was 17:00-20:59 in all nine selected Member States except Italy and Spain, where it was 21:00-23:59. The part of the day with the highest average hourly ratings was found to be the same for children 15-17 and for adults, namely 17:00-20:59 in the Czech Republic, Finland and the UK, and 21:00-23.59 in Austria, Germany, Italy, the Netherlands, Romania and Spain. ${ }^{13}$

Secondly, many of the media that are used on a daily basis by children do not fall within the scope of the Directive. As we noted back in 2013, audiovisual commercial communications are defined in the AVMS Directive as "accompany[ing] or [being] included in a programme in return for payment or for similar consideration or for self-promotional purposes". ${ }^{14}$ Consequently, promotional messages appearing on social media platforms, corporate websites, and user-generated video publishing websites such as YouTube are not covered by the Directive, as they are not included in a "programme", ${ }^{15}$ excluding a number of promotional techniques that are increasingly used to promote unhealthy food to children. ${ }^{16}$

Thirdly, the EU does not address marketing techniques that are particularly powerful at influencing children. In particular, no mention is made in the AVMS Directive of the use of celebrities, the use of licensed or equity brand characters, the offer of free toys... ${ }^{17}$

12 Case C-376/98 Germany v Parliament and Council [2000] ECLI:EU:C:2000:544.

13 ECORYS report, Study on the exposure of minors to alcohol advertising on TV and in online services (Brussels, March 2016), available at ec.europa.eu/digital-single-market/news/study-exposure-minors-alcohol-advertising-tv-andonline-services (last accessed 24 May 2017) and in particular section 4.2 on viewing patterns, at pp. 62-72.

14 Art. 1(h).

15 Bartlett and Garde, supra, note 9, 507. The possibility for children to access promotional messages for unhealthy commodities via YouTube is particularly concerning. See the conclusions of a study conducted on alcohol marketing: A Barry et al, "Underage Access to Online Alcohol Marketing Content: A YouTube Case Study" (2015) 50(1) Alcohol and Alcoholism 89.

16 See the discussion in E Boyland and M Tatlow-Golden's contribution to this Special Issue.

17 The argument could be made that these techniques may be regulated by Directive 2005/29 on unfair business-toconsumer commercial practices (UCP Directive): Directive 2005/29, OJ L 149, 11/6/2005, pp. 22-39. On the relationship between the AVMS Directive and the UCP Directive, see A Garde, "The Unfair Commercial Practices Directive: A Successful Example of Legislative Harmonisation?" in P Sypris (ed.), The Judiciary, the Legislature and 
Only the use of nutrition and claims made on food is addressed at EU level by Regulation 1924/2006 and requires prior-authorisation. ${ }^{18}$

The fact that the EU has not defined some of the key notions it relies upon makes the effectiveness of Article 9(2) even more doubtful. Firstly, the EU has not defined the term "children", thus leaving significant leeway to the signatories of the EU Pledge to define a child as less than 12 years of age. However, this definition does not recognise the growing research that demonstrates that teenagers' food preferences and consumption patterns are also negatively influenced by unhealthy food marketing. The EU-funded I-Family Study, which concluded in February 2017, is unequivocal in this respect, ${ }^{19}$ and adds to the research that the second contribution to this Special Issue has presented.

Moreover, by failing to adopt a nutrient profiling system, the EU has not provided any level playing field for the classification of foods into healthier or unhealthier categories. The question is left exclusively to the signatories of the EU Pledge (or to Member States that wish to exceed the minimum standard laid down by Article 9(2)). This failure does not come as a surprise, in that the European Commission never even fulfilled its legal obligation under Regulation $1924 / 2006^{20}$ to adopt a nutrient profiling scheme for the purposes of determining when nutrition and health claims can be made on food by the end of January 2009. ${ }^{21}$ However, this failure is extremely problematic in light of the objective of the WHO Recommendations to restrict the marketing of unhealthy food to children, as opposed to any food. ${ }^{22}$

In 2012, the Commission published its First Application Report on the AVMS Directive. ${ }^{23}$ After recognising that "Member States must encourage audiovisual media service providers to develop codes of conduct regarding inappropriate audiovisual commercial communications in children's programmes [for unhealthy food]", 24 the Commission called for "more effort [...] to create scale, support and best practice for codes of conduct on inappropriate commercial communications for [unhealthy food] targeting children. The effectiveness of such codes of conduct must be further assessed". ${ }^{25}$ The starting point for the revision of the AVMS Directive had therefore been set very low indeed. Since then, however, one could have hoped that the issue would have gained some momentum following the adoption of the EU Action Plan on Childhood Obesity 2014-2020. The Plan acknowledges the "strong link between TV

( $F^{\prime}$ note continued)

the Internal Market (Cambridge University Press, 2012); and A Garde, "Can the UCP Directive Really be a Vector of Legal Certainty?" in W Van Boom, A Garde and O Akseli (eds), The European Unfair Commercial Practices Directive: Impact, Enforcement Strategies and National Legal Systems (Abingdon, Routledge, 2014).

18 Regulation 1924/2006, OJ L 404, 30.12.2006, pp. 9-25.

19 www.ifamilystudy.eu, and in particular F van Meer, "Developmental differences in the brain response to unhealthy food cues: an fMRI study of children and adults" (2016) 104 American Journal of Clinical Nutrition 1515.

20 Regulation 1924/2006, supra, note 18.

21 Art. 4. On this question, see M Friant-Perrot and A Garde, "From BSE to Obesity: EFSA's Growing Role in the EU's Nutrition Policy" in A Alemanno and S Gabbi, Foundations of EU Food Law and Policy: Ten Years of the European Food Safety Authority (Farnham, Ashgate, 2013).

22 The WHO Commission on Ending Childhood Obesity clearly reiterated the importance for States to adopt nutrient profiling systems; Final Report (World Health Organization, Geneva, 2016).

23 Audiovisual Media Services and Connected Devices: Past and Future Perspectives, COM(2012) 203 final.

24 ibid 9.

25 ibid 11. 
and screen exposure and adiposity in children and young people" and called on the food industry to review and strengthen its commitments. In particular, it noted that "these efforts to restrict marketing and advertising to children and young people should include not only TV but all marketing elements, including in-store environments, promotional actions, internet presence and social media activities". ${ }^{26}$ Even though Member States recognise the limited scope of the EU Pledge, they did not envisage in the Plan the adoption of any legally binding rules - self-regulation remains the credo of the EU's response to the harmful impact of unhealthy food marketing on children's health. The gap between the global and unanimous commitment made by Member States at the World Health Assembly in May 2013 to halt the rise of childhood obesity by 2025 and what they seem to be prepared to do collectively at EU level has never seemed so wide. One can only deplore that this gap is most unlikely to be bridged any time soon.

\section{Fading hopes to witness the adoption of EU-wide legally binding and effective restrictions on the marketing of unhealthy food to children}

The Commission published a proposal for the revision of the AVMS Directive on 25 May $2016 .^{27}$ Referring specifically to the WHO Regional Office for Europe's nutrient profile model, ${ }^{28}$ the Commission noted that "Member States should be encouraged to ensure that self-and co-regulatory codes of conduct are used to effectively reduce the exposure of children and minors to audiovisual commercial communications regarding [unhealthy food]". ${ }^{29}$ As one could have expected following the 2012 Application Report, this proposal falls short of what is required to effectively protect children from the detrimental impact that unhealthy food marketing has on their health.

Firstly, as far as Article 9(2) specifically is concerned, the Commission has not proposed to supplement the EU Pledge with any EU-wide legally binding provisions. Instead, it has proposed that its wording should be slightly amended to address "the exposure of children and minors" to unhealthy food marketing, thus moving away from the narrow concept of "children's programmes". As discussed above and in other contributions to this Special Issue, the focus on exposure is key. Nevertheless, without any binding EU-wide harmonising standard, the proposal to amend the wording of Article 9(2) is unlikely to change the approach that the signatories of the EU Pledge have adopted, requiring that at least $35 \%$ of the audience is made up of children. The stance of the Commission is most disappointing in light of existing research showing: (1) the limits of self-regulation in contributing to positive, durable health outcomes; and (2) the importance of adopting comprehensive restrictions to unhealthy food marketing to ensure that industry operators do not shift their investment from regulated to unregulated programmes or from regulated to unregulated media.

Beyond the provisions concerning food marketing specifically, the Commission also proposes to liberalise the provisions of the Directive on the placement of advertising.

\footnotetext{
26 ibid 15.

$27 \operatorname{COM}(2016) 287$ final.

28 www.euro.who.int/en/health-topics/disease-prevention/nutrition/publications/2015/who-regional-office-for-europenutrient-profile-model-2015 (last accessed 24 May 2017).

29 Preamble, para. 10.
} 
Two provisions are particularly relevant. Firstly, Article 23 would be amended to contain a daily limit on television advertising rather than an hourly limit as things currently stand: "1. The daily proportion of television advertising spots and teleshopping spots within the period between 7:00 and 23:00 shall not exceed 20\%". This means that a broadcaster will have more flexibility to decide when to insert advertising and teleshopping spots in television programmes within the limits set by the Directive. One could venture the hypothesis that this will lead to more marketing in programmes with high audience thresholds, and less in programmes with lower audience thresholds - with an overall increase in exposure to marketing. Apart from the impact that this provision could have on the quality of the overall experience of viewers across Europe who will have to potentially cope with more advertising breaks than ever before, one can legitimately fear that this provision, if adopted, will lead to more exposure to advertising, irrespective of the calls on industry operators to adopt codes of conduct to limit such marketing. This is all the more likely as the $20 \%$ limit does not apply to: (a) announcements made by the broadcaster in connection with its own programmes; (b) sponsorship; and (c) product placement. Exposure to various forms of marketing will therefore exceed $20 \%$ overall if programmes are sponsored and include product placement.

Secondly, Article 11 in the new version proposed by the Commission would further liberalise product placement. In the current version of the AVMS Directive, Member States have an option to ban product placement or not. It is true that the ban on product placement would remain in children's programmes (as is currently the case) and would be extended to "programmes with a significant children's audience". This reflects the concern that children often are exposed to marketing even in programmes that are not classified as children's programmes. Unfortunately, however, the notion of "significant" seems to lay down a high threshold, which will in turn allow industry operators to continue to promote unhealthy food to children. This is particularly insidious in light of the report published on 25 May alongside the proposed revision of the AVMS Directive that children are affected by embedded marketing (focus of the study on online games) even though they do not always recognise it and that they openly declare not to like it.

It is true that the Commission has recognised that "new types of content, such as short videos or user-generated content, gain increasing importance and new players, including providers of video-on-demand services and video-sharing platforms, are now well established". ${ }^{30}$ However, the proposal also specifies that "social media services are not included, except if they provide a service that falls under the definition of a video-sharing platform". ${ }^{31}$ The scope of the AVMS Directive would therefore be slightly extended, ${ }^{32}$ but would still contain significant gaps, leaving major sources of unhealthy food marketing to children uncovered, notwithstanding their inherently cross-border nature. Furthermore, the Commission's proposal does not propose to ban unhealthy food marketing to children on video-sharing platforms. Rather, it merely refers to Directive 2005/29, which bans misleading, aggressive and otherwise unfair business-to-consumer

\footnotetext{
Preamble, para. 1.

Preamble, para. 3.

32 Insertion of Chapter IXa.
} 
commercial practices, defining the notion of "unfair" too narrowly as to be interpreted as supporting an EU-wide ban on unhealthy food marketing to children. ${ }^{33}$

Overall, therefore, the Commission has not taken on board all the evidence that has accumulated over the years on the exposure of children to alcohol and food marketing, including the evidence that it has commissioned itself. Its unshakeable, nonevidence based belief in the virtues of self-regulation is nothing short of "dogmatic". The Commission's reference to "effective enforcement" in the general provision it proposes to introduce on codes of conduct, "including when appropriate effective and proportionate sanctions". 34

The fact that "health" is hardly mentioned as a public interest worthy of consideration in the case supporting the Commission's proposal is most concerning, not least in light of the EU's duty to ensure a high level of public health protection in the development and implementation of all its policies. It is clear that the Commission has paid lip service to this obligation. ${ }^{35}$ This is particularly problematic for Member States that are keen to ensure that children's exposure to unhealthy food marketing is significantly limited. Is it not worth highlighting that the right to health is not mentioned alongside the right of commercial operators to trade, to property and to expression? There is admittedly a brief mention of the right of the child but it is not fleshed out: despite claims that the Commission is going to take the best interest of the child as a primary consideration (as mandated by Article 24 of the EU Charter on fundamental rights), there is no evidence that this has indeed been the case in this instance. $^{36}$

Civil society responded critically to the Commission's proposal. ${ }^{37}$ Nevertheless, their voice does not seem to have been heard: despite its significant shortcomings, the Commission's proposal is threatened to become even less effective in addressing unhealthy food marketing to children as the legislative process is unfolding. The final text that could ultimately be adopted at EU level may fall even shorter of evidence and be further diluted. "Cutting red tape", even if it is to the detriment of our most vulnerable consumers, has become the sole concern of an ultra-liberal EU.

On 10 May 2017, the Committee on Culture and Education presented its report on the revision of the AVMS Directive to the European Parliament. ${ }^{38}$ Apart from the continued emphasis on self-regulation and the proposal to suppress any reference to the WHO

33 Directive 2005/29, supra note 17; Garde (2012), supra, note 17; and Garde (2014), supra, note 17.

34 The Commission's reference to "effective enforcement" in the general provision it proposes to introduce on codes of conduct, "including when appropriate effective and proportionate sanctions" does not modify the assessment of the extent to which the Commission has failed to take evidence on board: see Art. 4(7).

35 See the Impact Assessment SWD(2016) 168 final, at p. 12; and the Ex-post REFIT evaluation of the AVMSD, $\operatorname{SWD}(2014) 170$ final, at p. 54.

36 The fundamental rights taken into consideration by the proposal are listed at p. 11 of the explanatory notes accompanying the proposal, and at para. 39 of the preamble. The rights of the child appears, but is not mentioned again, and the right to health, Art. 35 of the Charter, is not mentioned at all.

37 For example, nearly 40 children's rights, family, consumer, public health, alcohol control, and medical organisations called on Members of the European Parliament for ambitious action to free Europe's children, youth and parents from aggressive marketing of products harmful to health and future well-being: see epha.org/press-release-i-a-call-to-freeeuropes-youth-from-health-harmful-marketing/ (September 2016) (last accessed 24 May 2017). See also European Public Health Alliance, Self-regulation: a False Promise for Public Health? (2016), epha.org/wp-content/uploads/2016/12/SelfRegulation-a-False-Promise-for-Public-Health_EPHA_12.2016.pdf (last accessed 24 May 2017).

38 A8-0192/2017. 
Regional Office for Europe's Nutrient Profiling model, ${ }^{39}$ the Culture Committee has suggested that the Commission's proposal be amended to remove any reference to "programmes with a significant children's audience" (and maintain the existing wording of "accompanying or included in children's programmes"), as such notion is "neither clear nor legally sound, because programmes not initially targeting children, such as sport events or TV singing contests, may fall within this category". "Wasn't the whole idea precisely to address the exceedingly limited scope of the AVMS Directive and ensure that children exposed to unhealthy food marketing during sports events or TV singing contests would be effectively protected from such exposure? This position is all the more difficult to grasp if read in light of the proposal to require that the codes of conduct on unhealthy food marketing "shall aim to effectively reduce the exposure of children to audiovisual commercial communications for such foods and beverages". ${ }^{4}$ How does the Committee suggest that exposure will effectively be reduced if only children's programmes are included in the scope of the EU Pledge? This is counterintuitive and flies in the face of existing evidence. Nevertheless, at its plenary session on 18 May 2017, the European Parliament gave a mandate to the Culture Committee to start discussions with the Council on the basis of the amendments it had proposed to the Commission's proposal by 314 votes to 266 with 41 abstentions. ${ }^{42}$

The failure of the two rapporteurs of the Culture Committee, Sabine Verheyen and Petra Kammerevert, to act in light of the EU's mandate to ensure a high level of public health protection is resounding. Even industry actors themselves, the supposed beneficiaries of the Commission's mission to "cut red tape", have called on the EU to do more in helping them determine what should be seen as healthier or unhealthier food. On 15 May 2017, several major food manufacturers wrote an Open Letter to First VicePresident Frans Timmermans and other Commissioners jointly with major public health and consumer umbrella organisations urging the EU to "take decisive action" and adopt an EU-wide nutrient profiling system for nutrition and health claims "without further delay". ${ }^{43}$ Such a consensus is rarely seen in a policy area such as the regulation of food marketing where views have tended to be notoriously polarised.

Another curious feature of the legislative debate as it is unfolding at EU level is the divisions that seem to reign within the Commission itself. DG CONNECT is in the driving seat and its approach to the regulation of unhealthy food and alcohol marketing to children suggests that, despite the wide amount of evidence it has commissioned as

\footnotetext{
39 In the draft resolution, it is proposed to suppress all reference to the WHO nutrient profiling model: Amendment 13. For its part, the Internal Market referred to "national or international nutritional guidelines, such as the ones developed in the framework of the Commission's Platform for Action on Diet, Physical Activity and Health and the WHO Regional Office for Europe's nutrient profile model", thus putting the Platform commitments on the same level as the WHO's nutrient profiling model: Amendment 8.

40 Point VIII of the Explanatory Statement.

41 Amendment 63. See also Amendment 65 relating specifically to product placement: it is proposed to ban product placement in "children's programmes or content aimed primarily at children", rather than in "programmes with a significant children's audience", as the Commission had proposed.

42 www.europarl.europa.eu/news/en/press-room/20170511IPR74351/audiovisual-media-clear-rules-to-protect-children (last accessed 24 May 2017).

43 http://g8fip1kplyr33r3krz5b97d1.wpengine.netdna-cdn.com/wp-content/uploads/2017/05/Nutrient-profiles-letter.pdf? utm_source=POLITICO.EU\&utm_campaign=426e89058d-EMAIL_CAMPAIGN_2017_05_19\&utm_medium= email\&utm_term=0_10959edeb5-426e89058d-189884121 (last accessed 24 May 2017).
} 
part of the revision of the AVMS Directive, it still has very little understanding of the health issues at stake that call for an EU-wide response. By contrast, DG HEALTH AND FOOD SAFETY seems to understand the limits of self-regulation in policy areas where real or perceived conflicts of interest are unavoidable. The tensions are palpable. The Commission, however, is bound to speak with one voice; and in the current climate of neo-liberalism, DG HEALTH clearly does not have the loudest voice - if it has any voice at all! ${ }^{44}$

\section{RESTRICTING THE CROSS-BORDER MARKETING OF UNHEALTHY FOOD At Member State LEVEL}

In the previous section we have shown that the EU regulatory framework has failed to implement the WHO Recommendations effectively. As there is little hope that the revised version of the AVMS Directive currently under discussion is going to fill in the gaps that we have identified, this begs the question of the extent to which Member States can regulate individually the marketing of unhealthy food to children on their territories.

In this section, we argue that Member States should be able to use the clause of minimum harmonisation allowing them to exceed the standards established at EU level to implement the WHO Recommendations, and adopt comprehensive strategies to protect children from the harmful impact that food marketing has on their health. However, their freedom is subject to two legal requirements:

- firstly, compliance with the State of Establishment principle; ${ }^{45}$ and

- secondly, compliance with EU internal market law, and in particular the general provisions of the EU Treaties on the free movement of goods and free movement of services, which constitutes the focus of this section.

One of the most important challenges facing EU Member States is the cost and uncertainty that may be involved in defending the adoption of strong marketing restrictions intended to implement the WHO Recommendations. Any such action must take account of the legal requirements that Member States are subject to under EU internal market law.

Although Member States are granted a broad margin of discretion to adopt measures that may be trade-restrictive in order to protect public health, the extent of this discretion is subject to the pivotal proportionality principle. After establishing that measures restricting food marketing may infringe the free movement provisions of the EU Treaties (1), we focus on the margin of discretion that the Court's interpretation of the Treaty provisions has granted Member States, the evolution of the burden of proof that is placed on them when justifying their national measures, and the degree to which the imperative to protect children, and their health more specifically, bears on the proportionality analysis (2).

44 It is interesting that, only a few weeks after publishing a report on the labelling of alcoholic beverages, in which the Commission gave one year to the industry to propose "a harmonised approach aiming to provide consumers with information about the ingredients present in alcoholic beverages and the nutritional value of alcoholic beverages" (COM(2017) 58 final), Health Commissioner Vytenis Andriukaitis is due to participate in Eurocare seminar on "Self Regulation is No Regulation: The Case for Protecting Children from Alcohol Marketing": www.eurocare.org/media_centre/upcoming_events/ self_regulation_is_no_regulation_european_seminar_7_june_2017_brussels (last accessed 24 May 2017).

45 For a discussion of this principle, see Garde, supra, note 5; and Bartlett and Garde, supra, note 5. 
The final part of this section evaluates the implications of the Court's proportionality case law for Member States who, if they are to go beyond the scant provisions of the AVMSD in regulating the marketing of unhealthy food to children, must nevertheless do so in a way that respects their general EU Treaty obligations (3).

\section{Implementing the WHO Recommendations may require the adoption of trade restrictive measures}

The CJEU has broadly interpreted the scope of Articles 34 and 56 TFEU on the free movement of goods and services respectively, such that most restrictions on business practices that hinder or impede the free movement of goods or services - including many forms of marketing regulation - are likely to be caught. ${ }^{46} \mathrm{We}$ must therefore carefully categorise the range of marketing measures that Member States could adopt, to establish which are likely to be caught by the Treaty and which are not. The Court's case law has established four possible categories of measures:

- Measures that discriminate based on origin (for example, a ban on the marketing of certain products on the ground that they originate from other Member States), which always fall within the scope of the Treaty prohibitions and may only be justified in accordance with the derogations provided within the Treaties. Such measures are relatively rare and their justification places a high burden of proof on Member States because of their prima facie discriminatory nature. ${ }^{47}$ This would be the case if a Member State adopted a nutrient profile that would explicitly put its food manufacturers or producers at an advantage over other EU traders.

- Measures that do not explicitly discriminate but rather impose requirements that create a double regulatory burden for imported goods, which are always considered indirectly discriminatory and are therefore caught by the Treaty prohibitions. ${ }^{48}$ For example, marketing restrictions requiring changes in labelling or packaging, ${ }^{49}$ or which prohibit promotional content or gifts ${ }^{50}$ would fall within this category.

- Measures that place requirements on goods which are not discriminatory and which do not implicate cross-border movement in any way. These are measures that are outside the scope of the EU's internal market harmonisation powers, such as the regulation of adverts on "posters, parasols, ashtrays and other articles used in hotels, restaurants and cafés, and the prohibition of advertising spots in cinemas". 51 These measures fall outside the scope of the EU Treaties altogether and do not have to be

\footnotetext{
46 See Case C-8/74 Dassonville ECLI:EU:C:1974:82, para. 5, “all trading rules engaged by Member States which are capable of hindering, directly or indirectly, actually or potentially, intra-Community trade are to be considered as measure having an effect equivalent to quantitative restrictions"; and Case C-76/90 Säger ECLI:EU:C:1991:331, para. 12, "[Art. 56 TFEU] requires not only the elimination of all discrimination against a person providing services ... but also the abolition of any restriction, even if it applies without distinction ... when it is liable to prohibit or otherwise impede the activities of a provider of services".

47 See, for example, Case C-40/82 Commission v UK [1984] ECLI:EU:C:1984:33, para. 24, in which requiring importers of poultry meat from all Member States other than Ireland and Denmark to apply for a licence was caught by the treaty as a matter of course, but could potentially be justified.

48 Case C-120/78 Cassis de Dijon [1979] ECLI:EU:C:1979:42.

49 Case C-416/00 Moreallato [2003] ECLI:EU:C:2003:475.

50 Case C-368/95 Familiapress [1997] ECLI:EU:C:1997:325.

51 Germany v Parliament and Council, supra, note 12, para. 99.
} 
justified by Member States to be deemed compatible with EU law. ${ }^{52}$ For example, in Hünermund the CJEU concluded that a ban on advertising outside pharmacies would "not affect the marketing of goods from other Member States differently from that of domestic products". 53 In particular, Member States should be able to regulate in-school marketing without triggering their EU free movement obligations, thus implementing WHO Recommendation 5 that requires that "settings where children gather" should be free from unhealthy food marketing.

- The fourth category is significantly more difficult to define. It relates to the many marketing restrictions that do not impose any obvious barriers on intra-EU trade but nonetheless restrict market access. For example, if a country adopts television advertising restrictions, the question arises whether this measure - which seems to apply to all traders - does actually apply equally in law and in fact to them all or whether it puts foreign traders at a disadvantage. Regarding goods, even though a marketing measure may constitute a Keck selling arrangement and therefore fall prima facie outside the scope of Article 34 TFEU, ${ }^{54}$ it may still be caught on the basis that marketing restrictions can have an indirectly discriminatory effect on the free movement of goods, even if applied equally in law. Advocate General Jacobs observed in his Opinion in Leclerc-Siplec that:

in a developed market economy based on free competition the role of advertising is fundamental. Advertising is the means by which manufacturers and distributors of goods, and providers of services, seek to persuade consumers that their goods or services are worth buying ... Without advertising it would be extremely difficult for a manufacturer located in one Member State to penetrate the market in another Member State. ${ }^{55}$

Following this reasoning, the CJEU has concluded that "the possibility cannot be ruled out that to compel a producer to discontinue an advertising scheme which he considers to be particularly effective may constitute an obstacle to imports". 56 The position is similar for services. In Gourmet the Court held that a ban on advertising "even if it is non-discriminatory, has a particular effect on the cross-border supply of advertising space, given the international nature of the advertising market in the category of products to which the prohibition relates, and thereby constitutes a restriction on the freedom to provide services". 57 Therefore, marketing measures that only have a potential and indirect influence upon the free movement of goods and/or services might still fall within the scope of the EU Treaties and require justification. ${ }^{58}$

\footnotetext{
52 For commentary on the constitutional limits placed by Tobacco Advertising on the EU's ability to regulate advertising, see Geber, supra, note 7.

53 Case C-292/92 Hunermund [1993] ECLI:EU:C:1993:932, para. 23.

54 See Case C-267/91 Keck and Mithouard [1993] ECLI:EU:C:1993:905, para. 16.

55 Opinion of Advocate General Jacobs in Case C-412/93 Leclerc-Siplec [1995] ECLI:EU:C:1994:393, paras. 19-21.

56 Case C-239/02 Douwe Egberts [2004] ECLI:EU:C:2004:445, para. 52. See also Case C-34/95 De Agostini [1997] ECLI:EU:C:1997:344, para. 42; Case C-405/98 Gourmet [2001] ECLI:EU:C:2001:135, para. 21. For academic commentary, see A Kaczorowska, "Gourmet can have his Keck and eat it!" (2004) 10(4) European Law Journal 479; G Straetmans, "Case C-405/98, Konsumentombudsmannen (KO) v. Gourmet International Products AB (GIP), Judgment of the Court (Sixth Chamber) of 8 March 2001” (2002) 39 Common Market Law Review 1407.

57 Gourmet, ibid, para. 39.

58 On the increasingly broad scope of Art. 34 TFEU, see P Oliver, "Of trailers and jet skis: is the case law on Article 34 TFEU hurtling in a new direction?" (2009) 33 Fordham International Law Journal 1423. On Art. 56 TFEU, see
} 
Thus, the position currently appears to be that the CJEU will assume that any marketing measure with cross-border implications should fall within the scope of either Article 34 or 56 TFEU. Recently the CJEU even seems to be applying a pure market access test to public health measures, holding that measures such as the minimum unit pricing measure in Scotch Whisky ${ }^{59}$ fall within the scope of the free movement provisions without even categorising the restriction in question. ${ }^{60}$ This adds further weight to the presumption that a broad range of marketing measures will be caught by the Treaty. ${ }^{61}$

The significance of this for Member States wishing to implement the measures called for by the WHO Recommendations should not be understated. If a Member State's marketing measure is caught by the Treaty prohibitions, the Member State must be prepared to explain why a restriction to free trade - even one that is only indirect and completely unintentional should be tolerated, even if that restriction is created by the pursuit of public health objectives. This places the burden of proof on Member States to produce evidence to legitimise the regulatory choice that they have made. ${ }^{62}$ This process is all the more burdensome given that the CJEU is devoting increasing attention to proof and evidence in its review of justifications, ${ }^{63}$ as discussed below.

In summary, the CJEU's case law on the scope of Article 34 and 56 TFEU places Member States in a difficult position. On the one hand, they are expected to enact measures to restrict the marketing of unhealthy food to children (the WHO Recommendations). On the other, they are prohibited from enacting marketing measures that restrict intra-Union trade in goods and services (Articles 34 and 56 TFEU), except if they can explain how the measure's public health objectives can justify its trade-restrictive effects, which may be highly burdensome. ${ }^{64}$ However, in the next subsection we argue that Member States should not be discouraged from implementing the Recommendations. The justification of a trade-restrictive marketing measure depends on the proportionality of a measure.

\section{The proportionality of trade-restrictive controls on unhealthy food marketing to children}

If a trade-restrictive measure pursues one of the legitimate objectives set out in Article 36 TFEU or the mandatory requirement/objectives of general interest doctrine, and is

\section{(F'note continued)}

S Enchelmaier, "Always at your service (within limits): the ECJ's case law on Article 56 TFEU (2006-11)" (2011) 36(5)

European Law Review 615.

59 Case C-333/14 Scotch Whisky [2016] ECLI:EU:C:2015:845.

60 A Alemanno, "Balancing free movement and public health: the case of minimum unit pricing of alcohol in Scotch Whisky" (2016) 53 Common Market Law Review 1037, 1048-1049.

61 It is clear that, following the Commission v Italy and Mickelsson and Roos judgments, the idea of market access is now pivotal to the question of whether Art. 34 TFEU is breached: I Lianos, "In memoriam Keck: The reformation of the EU law on the free movement of goods" (2014) University College London CLES Research Paper Series 5/2014; M Jansson and H Kalimo, "De minimis meets 'Market Access': Transformations in the substance - and the syntax - of EU free movement law?" (2014) 51 Common Market Law Review 523.

62 D Wilsher, "Does Keck discrimination make any sense? An assessment of the non-discrimination principle within the European Single Market" (2008) 33(1) European Law Review 3.

63 N Nic Shuibhne and M Maci, "Proving public interest: The growing impact of evidence in free movement case law" (2013) 50(4) Common Market Law Review 965.

64 The Scotch Whisky litigation, initiated in the Scottish courts in 2012, is currently still on appeal to the UK Supreme Court, after the CJEU and Court of Session Inner House have ruled on the issue. 
compliant with the principle of proportionality, it may remain in place as a justified restriction on intra-EU trade. If these conditions are not met, the measure will be unjustified, and the restriction on trade will have to be removed.

It is well established that measures which seek to restrict the marketing of goods or services on public health grounds pursue a public interest objective. The connection between advertising restrictions generally and the protection of consumers and public health was established in several cases, not least Commission $v$ France (Loi Evin) ${ }^{65}$ and Gourmet, ${ }^{66}$ while the connection between food labelling requirements and the protection of consumer and public health was established in cases such as Van der Veldt ${ }^{67}$ and Solgar Vitamin's. ${ }^{68}$ In light of the evidence base supporting the WHO Recommendations (as presented in the second contribution to this Special Issue), ${ }^{69}$ it should now be relatively uncontentious that national measures imposing restrictions on unhealthy food marketing to protect children's health pursue a legitimate objective.

The Court's case law recognises that Member States benefit from a broad margin of discretion as to how they pursue legitimate public health protection objectives, and that their discretion may be exercised "having regard to the particular social circumstances and to the importance attached by those States" ${ }^{, 70}$ to the public health objective.

This is not to say, however, that this discretion is unlimited. Even though Member States are primarily responsible for the health of their citizens, the fact remains that "the burden of proving circumstances justifying a derogation from the principle of the free movement of goods rests on [them]". ${ }^{71}$ Discharging this burden of proof requires that the Member State concerned establishes that the measure complies with the principle of proportionality.

To be proportionate, a measure must be "appropriate to secure the attainment of the objective which they pursue and not go beyond what is necessary in order to attain it". 72 While several efforts have already been made at national level to regulate unhealthy food marketing to children, as discussed in this Special Issue, none have adopted broad statutory prohibitions on such marketing, which would amount to a comprehensive approach according to WHO Recommendations 2 and 3. As the CJEU has not had the occasion to examine the proportionality of national food marketing restrictions with the EU Treaty, we analyse relevant CJEU case law on marketing, food regulation, and the protection of children, to explore how such measures could be assessed.

The intensity of the CJEU's proportionality review depends on the severity of the restriction placed upon trade. For total bans on advertising, the burden of proof resting

\footnotetext{
65 Case C-262/02 Commission v France (loi evin) [2004] ECLI:EU:C:2004:431, para. 30.

66 Gourmet, supra, note 56.

67 Case C-17/93 Van der Veldt [1994] ECLI:EU:C:1994:299, para. 29.

68 Case C-446/08 Solgar Vitamin's [2010] ECLI:EU:C:2010:233.

69 The connection between the protection of public health and the need to restrict marketing should be made. For an example where the packaging requirements were not sufficiently connected to the protection of public health, see: Moreallato, supra, note 49, para. 40.

70 Case C-434/04 Ahokainen [2006] ECLI:EU:C:2006:609, para. 32.

71 Case C-304/84 Muller [1986] ECLI:EU:C:1986:194, para. 17.

72 Commission v France, supra, note 65, para. 24.
} 
on the Member States is high. ${ }^{73}$ However, the case law that deals directly with total advertising bans, as in Gourmet, does not indicate that such a measure can never be justified. Rather, these cases have simply indicated that the referring national court is to have the final say on proportionality, and that total advertising bans are not contrary to Article 34 "unless it is apparent that, in the circumstances of law and of fact which characterise the situation in the Member State concerned, the protection of public health against the harmful effects of alcohol can be ensured by measures having less effect on intra-Community trade". ${ }^{74}$ While the Swedish court in Gourmet proceeded to hold that the impugned ban on alcohol advertising across a range of media was disproportionate, the most that this tells us is that the fate of a total ban on advertising is determined by the ability of the Member State to show, with evidence, that another measure would not achieve as effectively the public health objectives that are sought.

The Scotch Whisky litigation provides an excellent example - the Scottish government may not have framed its minimum unit pricing measure or presented its evidence as effectively as it could have done before the CJEU, resulting in an ambivalent decision on proportionality. Before the Inner House of the Court of Session, however, the Scottish government was given the opportunity to revise and renew its presentation of the evidence base, and as a result the Inner House delivered a judgment that rules that the measure was proportionate. Thus, for any stringent public health measure, whether it be total bans on advertising or setting price floors, the proportionality of measures is determined though engagement with evidence.

Where less stringent or partial prohibitions on advertising or labelling are at issue, the CJEU is more likely to find national measures to be proportionate. In Van der Veldt for example, the CJEU noted that "labelling is one of the means that least restricts the free movement of products within the Community", 75 and such measures fulfilled the obligation to be "not out of proportion to the desired result and ... hinder as little as possible the importation of products". 76

Thus, one might tentatively conclude that the narrower in scope an advertising measure is, the more likely it is to be proportionate, although scope alone is not determinative of proportionality. It is apparent that there is a general trend towards a closer and more empirical evaluation of the proportionality of Member State public health measures. ${ }^{77}$ Elsewhere, and in relation to alcohol marketing, the CJEU tended to engage less rigorously with proportionality in its earlier public health case law, ${ }^{78}$ this appears to be the case for food marketing too - for example in the Douwe Egberts decision in 2004 the CJEU based its proportionality analysis partly on an "assumption" of the conceivability of the existence of risk. ${ }^{79}$ However as Shuibhne and Maci

\footnotetext{
73 Douwe Egberts, supra, note 56, para. 44; Case T-100/15 Dextro Energy [2016] ECLI:EU:T:2016:150, paras. 82-83.

74 Gourmet, supra, note 56, para. 34.

75 Van der Veldt, supra, note 67, para. 31.

76 ibid para. 30.

77 See Alemanno, supra, note 60, 1048-1049; O Bartlett and A Garde, "EU public health law and policy - on the rocks? A few sobering thoughts on the growing EU alcohol problem" in T Hervey et al., Research Handbook on EU Health Law and Policy (Cheltenham, Edward Elgar, 2017).

78 ibid.

79 Douwe Egberts, supra, note 56, para. 41.
} 
demonstrate, the "relevance of proof has clearly acquired enhanced significance in more recent free movement case law". 80 Their analysis, published in 2013, has been further strengthened by the CJEU's decision in Scotch Whisky of December 2015, in which the CJEU engaged in some detail with the evidence submitted.

Member States wishing to implement the WHO Recommendations should pay close attention to the application of proportionality in Scotch Whisky. The Court appeared to ask whether minimum unit pricing (MUP) "offered anything more towards the achievement of the legitimate objective than the alternatives", 81 rather than whether the alternatives would be as effective. This subtle shift in emphasis is important, as it appears to generate an evidentiary burden on Member States that is at odds with the margin of discretion doctrine that has been espoused by the Court in most of its previous public health case law. ${ }^{82}$ Nevertheless, the CJEU did clarify that Member States do not have to "prove, positively, that no other conceivable measure could enable the legitimate objective pursued to be attained under the same conditions", 83 but rather must demonstrate that it "may reasonably be concluded from the evidence submitted" 84 that the chosen measure is appropriate and necessary.

Member States should note that this does not necessarily mean demonstrating that advertising alone will reverse growing childhood obesity rates. This would be simply impossible, as there is no "magic bullet" able to solve the problem: effective strategies will need to be multi-pronged. ${ }^{85}$ The General Court showed in Dextro Energy that the EU judicial institutions are increasingly aware of the confluence of evidence supporting action on obesity prevention, ${ }^{86}$ and the Scotch Whisky decision showed that the EU judiciary is aware that public health strategies are often comprised of multiple interlinking policies. ${ }^{87}$ Member States should, however, ensure that they approach the justification of controls on unhealthy food marketing with a clear idea of what the precise public health objectives of said marketing controls are, and how the evidence base supports their adoption. Fortunately for Member States, an ideal starting point for this is provided by the WHO Recommendations themselves, and other WHO reports and strategies concerning childhood obesity, as other contributions in this Special Issue have highlighted.

Member States should be further encouraged by the way in which the CJEU has developed its jurisprudence on the proportionality of measures where the protection of children's health is specifically at stake. In earlier public health and consumer protection case law, even that which specifically concerned measures designed to protect children, the CJEU paid little attention to the nature of the public health interest

\footnotetext{
80 Nic Shuibhne and Maci, supra, note 63, 1005.

81 Bartlett and Garde, supra, note 79.

82 See Alemanno, supra, note 60, 1060.

83 Scotch Whisky, supra, note 59, para. 55.

84 ibid, para. 56.

85 A Garde, "Freedom of Commercial Expression and Public Health Protection: The Principle of Proportionality as a Tool to Strike the Balance" in L Gormley and N Nic Shuibhne (eds), From Single Market to Economic Union - Essays in Honour of John Usher (Oxford, Oxford University Press, 2012) 117.

86 Dextro Energy, supra, note 73, paras. 47-50.

87 Scotch Whisky, supra, note 59, para. 38.
} 
being pursued. For instance, in De Agostini the Court acknowledged that "the protection of consumers in general are overriding requirements of general public importance", 88 but declined to mention the protection of children specifically. In Muller, which concerned prohibitions on food additives, the CJEU noted evidence from the French government that children were major consumers of products likely to contain allegedly harmful additives, however, it went no further in factoring the protection of children specifically into its decision on proportionality. ${ }^{89}$ Even in its tobacco judgments at the turn of the century, the protection of children's health was absent from the analysis of proportionality. ${ }^{90}$

However, the CJEU has given more attention recently to specific populations targeted by health protection measures. In Pillbox 38, the CJEU noted that "young people who are particularly sensitive to advertising" $" 91$ would be exposed to fewer promotional messages as a result of a general ban on electronic cigarette advertising - an outcome that did not exceed the limits of what was necessary to protect public health. In Solgar Vitamin's, a certain level of public health protection that is "appropriate for a specific group of consumers, such as children", could be applied to the whole population as long as the measure is "limited to what is necessary to protect the health of the persons belonging to that group". ${ }^{92}$ Further tobacco case law reflects clear concern for the protection of children's health. ${ }^{93}$ This more recent jurisprudence potentially indicates that measures specifically crafted to afford a high level of protection to young people might be more likely to be seen as necessary to protect public health.

\section{Implications for the reconciliation of WHO commitments and internal market obligations}

What are the implications of the foregoing analysis for Member States seeking to implement the WHO Recommendations? The Court's case law establishes that Member States must demonstrate, through the use of evidence, that trade-restrictive marketing measures adopted to implement the WHO Recommendations are necessary and appropriate to achieve the legitimate objective of protecting public health, if they are to comply with EU free movement law. Furthermore, the more stringent the restriction, the heavier the burden of proof on Member States will be. Given that the Recommendations call for strong controls on marketing, Member States must be prepared to mount a rigorous defence of any such measures that they adopt. This is very likely to happen, despite the unanimous recognition by the World Health Assembly that such measures should be adopted: one can learn from the many challenges that tobacco manufacturers have mounted against the implementation by States of the Framework Convention on Tobacco Control. However, it is precisely this fact that should embolden Member States to implement the WHO Recommendations, and which should put them

\footnotetext{
88 De Agostini, supra, note 56, para. 46.

89 Muller, supra, note 71, para. 18.

90 See for example Case C-491/01 British American Tobacco [2002] ECLI:EU:C:2002:741.

91 Case C-477/14 Pillbox 38 [2016] ECLI:EU:C:2016:324, para. 113.

92 Solgar Vitamin's, supra, note 68, para. 61.

93 Philip Morris Brands, supra, note 5.
} 
on the front foot when articulating the evidence to support their regulatory choices. The earlier they frame their policies in light of existing evidence, the more likely they are to succeed in defending industry-led challenges.

Member States should not, therefore, refrain from placing the strongest of restrictions upon unhealthy food marketing to protect children. The CJEU's case law indicates that if Member States can provide evidence to demonstrate that their measures are necessary, then these measures will be proportionate and therefore compatible with the EU Treaties. Nothing in the CJEU's case law indicates that the stringency of a measure alone will be fatal in determining its proportionality. Should Member States restrict unhealthy food marketing as comprehensively as possible in light of WHO Recommendations 2 and 3, the key issue for them will be supplying the CJEU with evidence that will demonstrate that preventing adults from being exposed to certain marketing messages for unhealthy food is necessary in order to protect children from the damaging effects that exposure to those marketing messages have on their health. Member States should, therefore, present the evidence base supporting the implementation of the WHO Recommendations as clearly and unequivocally as possible. Since Scotch Whisky, it is evident that the CJEU is willing to engage in closer proportionality reviews of national public health measures, placing more emphasis on evidence than it used to.

Finally, we might note with optimism that the CJEU has recently placed greater emphasis on the external public health commitments of the Member States. For example, in its recent case law upholding the validity of the Tobacco Products Directive, the CJEU made specific mention of the guidelines drawn up to support the implementation of the Framework Convention on Tobacco Control. It stated that while the guidelines are nonbinding they are intended to assist the adoption of measures in accordance with the FCTC, ${ }^{94}$ and "are based on the best available scientific evidence and the experience of the Parties ... and have been adopted by consensus", 95 and as such "are intended to have a decisive influence on the content of the rules adopted in the area under consideration". 96 This might be considered encouraging for Member States seeking to use the WHO Recommendations as a basis upon which to implement stricter marketing measures: while the WHO Recommendations are not, by nature, legally binding, they are nonetheless based on accumulated scientific evidence on the harmful impact of unhealthy food marketing on children, they have been adopted by unanimous consent, and they are intended to guide state action in the field of obesity prevention. Therefore, the potential role of the WHO Recommendations themselves in influencing the direction of the proportionality analysis should not be overlooked. ${ }^{97}$

\footnotetext{
94 Phillip Morris Brands, supra, note 5, para. 111.

95 ibid, para. 112.

96 ibid, para. 113.

97 One should also note that the WHO Recommendations urge the Member States to include monitoring and evaluation provisions in any policy frameworks they adopt. The inclusion of sunset clauses in these policy frameworks (in which Member States formally commit to review legislation in light of evidential developments) based on the commitment to policy learning encouraged by the WHO Recommendations could increase the proportionality of controls on food marketing to children; Scotch Whisky, supra, note 59, para. 57, and the Opinion of the Advocate General at para. 85. See also S Veit and B Jantz, "Sunset Legislation: Theoretical Reflections and International Experiences" in A Alemanno et al (eds), Better Business Regulation in a Risk Society (New York, Springer, 2013) 267.
} 


\section{CONCLUSION}

Considering that most food and beverage marketing is conducted by multinational corporations with global supply chains and international reach, ${ }^{98}$ which promote their goods, services and brands across national borders, the EU would seem in a much better position to tackle the harmful impact that unhealthy food marketing has on children's health by harmonising the laws of the Member States, rather than leaving them to grapple with the issue individually. However, in the absence of any political will at EU level to effectively limit the exposure of children to unhealthy food marketing, it is imperative that Member States use their discretion to exceed the minimum (and minimal) standards set at EU level to ensure that they comply with their international commitment to protect children from the impact of such marketing and therefore try and halt the rise of childhood obesity by 2025. In doing so, they should be mindful of the process through which they may have to justify the adoption of national measures on unhealthy food marketing, as such measures could restrain the free movement of goods and services and fall within the scope of EU internal market law.

98 See, for example, D Stuckler et al., "Manufacturing epidemics: The role of global producers in increased consumption of unhealthy commodities including processed foods, alcohol and tobacco" (2012) 9(6) PLoS Med e1001235. 